\title{
Feed milling for ruminant animals according to demands of organic farming in conditions of the South of Ukraine
}

\author{
Yu. Vdovychenko, \\ Corresponding Member of NAAS, doctor of agricultural sciences, Ukraine
}

\author{
A. Gratylo, \\ candidate of agricultural sciences
}

\section{H. Smenova}

\author{
Ascania Nova Institute of Animal Breeding in the Steppe Regions named after M. F. Ivanov - \\ National Scientific Selection-Genetics Center for Sheep Breeding
}

The purpose. To develop a technique for agro-ecological production of feedstuff for ruminant animals in conditions of bogharic agriculture of the South of Ukraine according to demands of organic farming which will promote deriving of highly nourishing and qualitative vegetable products without pollutants. Methods. Field and laboratory trials. Results. Use of perspective innovative grades of forage grasses and biological preparations promoted an increase of yield of perennial forage grasses, drought-enduring annual forage crops and as a result deriving pollution-free feedstuff. The content harmful matters, pollutants and heavy metals in samples of the gained feedstuff did not exceed maximum concentration limit. Conclusions. The technique of agro-ecological production of feedstuff is developed for ruminant animals according to demands of organic farming in conditions of bogharic agriculture.

Key words: bogharic agriculture, animals, pascual conveyor, bacteria preparations, pollutants, feedstuff, efficiency.

The current state of agriculture in the world and in particular in Ukraine, according to scientists is tense and complicated. World production of crops and their pollution has become a reality. [1]

Further intensification of agriculture as a way to increase of its productivity, mostly exhausted, and the negative consequences require finding alternative ways of farming. One of these areas is the greening of industry, components of which are elements of farming with appropriate environmental restrictions. Despite the lack of scientific substantiation of the concept of alternative farming, the interest in this problem in the world and in Ukraine is extremely high [2,3].

An important way of biologization and greening of crop production is the development of the technology elements of effective application of biological products that based on the promising strains nitrogen fixing and phosphate mobilizing bacteria, microorganisms and bacteria (which stimulate growth) for growing pulses and cereals, and the micro-bio methods of protection of the plants $[4,5]$.

The main source of the fodder production is the field's fodder production. Its priority direction is the biologization of processes in specific climatic areas with the environmental efficiently using of soil fertility. First - this is the improving of the structure of grass cultivation, and the development of pasture and raw conveyor. By these elements of the agro technology provide the valuable feeding and will promote the increasing of animal productivity [6-11].

In addition, the production technology of certain types of feed that are in the area of the southern steppe has a high-cost, and it is not helping to reduce the costs, so it ultimately leads to reduce the competitiveness of animal products. This requires the development and implementation of energy efficient technologies and methods of production of green, coarse and succulent fodder and the development of the optimal structures of the acreage of the forage cereals crops [12].

However, in a complex of measures aimed to increase the productivity of grasslands and pastures, it is necessary to improve the agrophytocenoses based on full utilization of the genetic potential of forage 
plants of native flora and created new varieties and hybrids, and optimize the conditions for their functioning based on advanced technologies [13].

All this requires improvement of existing and development of the new methods of creation of agrocenoses for farm animals, so as optimization of the structure of sown areas under the conditions of current agro ecological production in order to obtain a highly quality forage while maintaining ecological stability in agro ecosystems. [14]

The purpose of researches - to develop technology agro ecological production of feed for farm animals according to the requirements of organic farming under the conditions of dryland in the south of Ukraine, which will facilitate obtaining of high quality plant products free of contaminants.

Conditions and methodology of researches. Research work was performed in conditions of dryland farming on the lands SE "RE IABSR " Ascania Nova " - NSSGCSB" using the laboratory and field methods.

We used meteorological data of the meteorological station of Askania Nova town (Table. 1).

Soils - dark brown, slightly salty, medium loam. The arable layer contains: $2,2-2,8 \%$ of humus, nitrogen $-0.17 \%$ phosphorus $-2,4-4,0 \mathrm{mg}$ potassium - $40 \mathrm{mg}$ per $100 \mathrm{~g}$ of absolutely dry soil. In the field water capacity of the meter layer soil $-20.5 \% ; 9.5 \%$ wilting humidity, density assembly $-1.47 \mathrm{~g} / \mathrm{cm} 3$.

The climate of southern steppe of Ukraine is temperate continental with frequent dry winds. The growing season lasts $210-220$ days. The annual sum of temperatures higher than $10^{\circ} \mathrm{C}-2600-2800$. The quantity of rainfalls on average according to long-term data is $390 \mathrm{~mm}$ per year.

During the years, when researches were carrying out, the weather conditions were different according to data of rainfalls and temperature regimes. Thus, the amount of average temperature during the growing season from April to October ranged over the years from 120.2 to $138.5^{\circ} \mathrm{C}$ with medium index for many years $-117.4^{\circ} \mathrm{C}$, so it exceeded the average figure on $2,8-21,1^{\circ} \mathrm{C}$.

Total rainfall for the period from April to October had significant variations those were within 200,3$376,6 \mathrm{~mm}$ and average data during many years $-270 \mathrm{~mm}$. The wet year was $2011(376,6 \mathrm{~mm})$. Very dry weather was in 2012, the precipitation fell to $200.3 \mathrm{~mm}$, while their number in 2010, 2013 and 2014 were 234.8, 268.4 and $241.7 \mathrm{~mm}$, respectively, in 2015 - $239.7 \mathrm{~mm}$.

Humidity of air also varied by years of researches. High humidity in the growing season there was in $2010-67.8 \%$, in 2014 and 2012 these figures were the lowest $-61,0-61,4 \%$, and in 2011, 2013 and 2015 were within $63.5-66.4 \%$.

Table 1. Main meteorological indicators during the growing season according to the data of agro meteorological station Askania Nova town (2010-2015).

\begin{tabular}{|c|c|c|c|c|c|c|c|c|}
\hline \multirow{2}{*}{ Years } & \multicolumn{7}{|c|}{ Months } & \multirow{2}{*}{$\begin{array}{l}\text { Total I } \\
\text { Averag } \\
\text { e }\end{array}$} \\
\hline & IV & $\mathbf{v}$ & $\mathbf{V I}$ & VII & VIII & $\mathbf{I X}$ & $x$ & \\
\hline \multicolumn{9}{|l|}{ Precipitation, $\mathrm{mm}$} \\
\hline 2010 & 12,2 & 22,8 & 102,4 & 70,6 & 0,6 & 18,0 & 8,2 & 234,8 \\
\hline 2011 & 81 & 49,6 & 98,1 & 80 & 40 & 13,4 & 14,5 & 376,6 \\
\hline 2012 & 21,4 & 55,4 & 30,5 & 22,4 & 55,4 & 1,8 & 13,4 & 200,3 \\
\hline 2013 & 3,7 & 6,3 & 67,8 & 87,2 & 20,0 & 28,5 & 55,4 & 268,9 \\
\hline 2014 & 10,3 & 15,6 & 91 & 0 & 38 & 47 & 39,8 & 241,7 \\
\hline 2015 & 34,7 & 44,1 & 51,0 & 61,6 & 18,3 & 5,0 & 25,0 & 239,7 \\
\hline $\begin{array}{l}\text { Average } \\
\text { during many } \\
\text { years }\end{array}$ & 36 & 38 & 59 & 38 & 36 & 36 & 27 & 270 \\
\hline
\end{tabular}




\begin{tabular}{|c|c|c|c|c|c|c|c|c|}
\hline \multicolumn{9}{|l|}{ Air temperature, ${ }^{\circ} \mathrm{C}$} \\
\hline 2010 & 10,2 & 17,2 & 22,5 & 24,7 & 27,5 & 18,0 & 8,2 & 128,3 \\
\hline 2011 & 8,2 & 14,8 & 21,6 & 25,3 & 22,3 & 18,3 & 9,7 & 120,2 \\
\hline 2012 & 13 & 20,1 & 22,8 & 25,4 & 23,9 & 18,7 & 14,6 & 138,5 \\
\hline 2013 & 11,5 & 20,1 & 22,9 & 23,6 & 24,4 & 14,9 & 8,7 & 126,1 \\
\hline 2014 & 10,4 & 17,9 & 20,5 & 25,0 & 24,5 & 18,1 & 8,8 & 125,2 \\
\hline 2015 & 9,0 & 15,9 & 21,5 & 23,1 & 24,3 & 20,6 & 9,2 & 123,6 \\
\hline $\begin{array}{l}\text { Average } \\
\text { during many } \\
\text { years }\end{array}$ & 9,7 & 15,4 & 20,1 & 23,3 & 22,3 & 16,5 & 10,1 & 117,4 \\
\hline \multicolumn{9}{|l|}{ Air humidity, \% } \\
\hline 2010 & 64,0 & 72,0 & 71,3 & 71,0 & 50,6 & 65,0 & 81,0 & 67,8 \\
\hline 2011 & 68,0 & 73,3 & 61,6 & 75,0 & 57,3 & 58,6 & 71,3 & 66,4 \\
\hline 2012 & 67,3 & 61,3 & 60,0 & 53,3 & 54,0 & 61,6 & 72,6 & 61,4 \\
\hline 2013 & 65,3 & 57,0 & 59,3 & 57,0 & 50,6 & 71,0 & 84,0 & 63,5 \\
\hline 2014 & 66,3 & 68,6 & 64,3 & 59,6 & 49,6 & 56,0 & 72,6 & 61,0 \\
\hline 2015 & 71,3 & 66,0 & 65,0 & 65,7 & 50,3 & 62,0 & 64,0 & 63,5 \\
\hline $\begin{array}{l}\text { Average } \\
\text { during many } \\
\text { years }\end{array}$ & 73,0 & 68,0 & 64,0 & 59,0 & 59,0 & 67,0 & 77,0 & 66,7 \\
\hline
\end{tabular}

The study was conducted using the "Methods of conducting experiments on fodder production" [15]; "Methods of experiments for hay making and pasture" [16] "Methods of field experiments" [17].

Agrotechnics of cultivation of fodder crops is common to southern Ukraine. When we were creating a perennial and annual herbages had used such drought resistant crops of the zoned varieties and hybrids of local breeding and from the other regions as: Psathyrostachys juncea (Fisch.) Nevsky 14/08, Agropyron pectin forme Askania Nova, Bromus inermis Skiff, Onobrychis arenaria Ingulsky, Sorghum vulgare Pers. x Sorghum sudanense (Piper) Stapf (hybrid) Juicy stem 3, Sorghum x drummondii Multiharvest, Sorghum saccharatum (L.)Moench mid-ripening Crimean 15, middle-early corn Etiud, Amaranthus Atlant, Glycine max Vityaz 50.

Sorghum vulgare Pers. $x$ Sorghum sudanense (Piper) Stapf hybrid had seeded with seeding rate of 150 and 200 thousand / ha plants with row spacing of 30-45 cm. Sudan grass and soybean had sown at a ratio of components $70+30 \%$. One-species sugar sorghum crops were seeded with seeding rate of 100 thousand / hectare plant, corn - 30 thousand / hectare plant, their sowing compatible with Amaranth - 100 +85 and $30+85$ thousand / ha plants respectively.

The phenological monitoring of the growth and development of plants was conducted during the experiments.

The accounting of the yields of green mass on plots of $40 \mathrm{~m}^{2}$ was held during the period of economic maturity of crops (pasture, hay making). Repetition - 3 times during experimental period. The samples of green mass $(1 \mathrm{~kg})$ from the first and third repetition for chemical analysis and determination of the yield of hay had been selected. During the registration of the herbages yield, their botanical composition had determined by the way of the choice on the groups of plants from the test sheaf $(1 \mathrm{~kg})$ of the first and third repetition of the experiment [16].

According to the recommendations of the effective application of microbial agents in crop growing technologies, in the research studied the effect of biological products of various functional effects on yield and quality of green mass of agrophytocenoses, which were created. Seeds of the cereal crops before 
sowing treated with a mixture of drugs - diazofit+ biopolitsyd + fosfoenteryn; beans - ryzobofit + biopolitsyd + fosfoenteryn. Inoculation of seeds was spent in a sowing day [18].

For conditions of the steppe zone of the south of Ukraine based on conventional technologies of growing of forage crops were developed: technological maps, determined the costs of growing crops, a comparison of economic efficiency, taking into account production costs, yield, content of feed units and digestible protein. When calculating the cost of 1 centner of each crop products we used actually acting, at the moment of making the technological cards, purchase prices for seeds, fuel, pesticides, and fertilizers.

The results of researches. Over the years studies (2010-2015rr.) on the pasture and hay making agrocenoses the yield of perennial grass mixtures (Onobrychis arenaria with Psathyrostachys juncea (Fisch.) Nevsky , Agropyron pectin forme or Bromus inermis) in a pasture phase of maturity (10.0520.05) was 114,0-140,6 cwt / ha and the highest was in Bromus inermis - $140.6 \mathrm{cwt} /$ ha (control 109,8$135,9 \mathrm{cwt} / \mathrm{ha}$ ), increase of yield relative to control amounted 4,2-6,9 cwt / ha or 3,6-5,9\%. Out of dry matter was $23,4-28,8 \mathrm{cwt} / \mathrm{ha}$, of fodder units - 15,6-20,6 cwt / ha and digestible protein - 1,65-2,90 cwt / ha (Table 2).

Leguminous component of these grass mixtures (Sainfoin sandy) completely dropped out of the herbage on the fourth year of their using.

Two dates of sowing the Sorghum Sudanese hybrid (05-10.04 and 20-30.05) had provided an average income of pasture feed from the second decade of June to the second decade of August, and from aftergrass - from the second decade of July to October inclusive, for 150 days.

The first date of sowing, during two or three cycles of use, had provided an average yield of pasture forage $273.5 \mathrm{cwt} /$ ha that exceeded the control by $46.1 \mathrm{cwt} /$ ha or $20.3 \%$ (control $227.4 \mathrm{cwt} / \mathrm{ha}$ ). In the experimental version the getting of dry matter was $44.7 \mathrm{cwt} /$ ha of fodder units - $33.4 \mathrm{cwt} /$ ha, digestible protein $-4.7 \mathrm{cwt} / \mathrm{ha}$.

The second date of sowing, during two cycles of use, had provided the yield of green mass on average $175.4 \mathrm{cwt} / \mathrm{ha}$, which exceeded the control by $28.4 \mathrm{cwt} /$ ha or $19.3 \%$ (control $147.0 \mathrm{cwt} / \mathrm{ha}$ ). Gathering of dry matter in the experimental variant was $29.1 \mathrm{cwt} /$ ha with an output of feed units $23.2 \mathrm{cwt}$ / ha, digestible protein - $3.3 \mathrm{cwt} / \mathrm{ha}$. The average yield for the period of use of the two terms of crop was $224.5 \mathrm{cwt} / \mathrm{ha}$ (control $187.2 \mathrm{cwt} / \mathrm{ha}$ ).

In experiment to determine the dates of using the herbages of sugar sorghum "Crimea 15" and its stern performance depending on the ways of sowing and seeding rates it was determined that since the second decade of June to the second decade of July it can be used as a pasture. The average yield at the pasture maturity phase (15.06 and the aftergrowth 15.07$)$ with the seeding rate of 150 thousand / hectare plant was 209, 4-210, $0 \mathrm{cwt} /$ ha (control 160, 7-199, $9 \mathrm{cwt} / \mathrm{ha}$ ). Productivity gain compared with the control was 2, 5-29, $3 \mathrm{cwt} /$ ha or $4,8-16,2 \%$. The highest yield was observed in the variant with row spacing of 30-45 cm - 209, 4-210, $0 \mathrm{cwt} / \mathrm{ha}$. Collection of dry matter was $63.58 \mathrm{cwt} / \mathrm{ha}$ of fodder units $56.6 \mathrm{cwt} / \mathrm{ha}$, digestible protein $-4.67 \mathrm{cwt} / \mathrm{ha}$. At norm of seeding of 200 thousand / hectare, the plants' productivity was 94, 1-196, $2 \mathrm{cwt} /$ ha (control 181, 9-186, $2 \mathrm{cwt} /$ ha), the increase amounted 14, 3-7, 9 cwt / ha or $7.9-4,2 \%$. The highest yield is also observed in the variant with row spacing of $30 \mathrm{~cm}-196.2$ cwt / ha. Collection of dry matter in this variant was $59.74 \mathrm{cwt} / \mathrm{ha}$, of fodder units $-52.35 \mathrm{cwt} / \mathrm{ha}$ and digestible protein $-4.26 \mathrm{cwt} /$ ha.

Thus, perennial herbages, which were seeded in the 2010 , at the phase of pasture maturity had provided the yield of green mass 114,0-140,6 cwt / ha that containing 23,4-28,8 cwt / ha dry matter, 15,6$20,6 \mathrm{cwt} / \mathrm{ha}$ feed units and 1,65-2,90 cwt / ha of digestible protein.

Different dates of sowing the Sorghum Sudanese hybrid had provided the income of pasture feed from the second decade of June to October inclusive, for 150 days with average yield of $224.5 \mathrm{cwt} /$ ha of green mass, which exceeded the control at $46,1-28,4 \mathrm{cwt} /$ ha or $20,3-19,3 \%$.

The agrocenoses of sugar sorghum in a pasture phase of maturity, which had the $30-45 \mathrm{~cm}$ row spacing and seeding rate of 150-200 thousand / ha plants, that were treated in preplant period with bacterial agents had provided the highest yield of green mass - 209,0-194,1 cwt / ha, dry matter fee - 63,58- 59.74 cwt / ha, fodder units - 56,6-52,35 cwt / ha, digestible protein - 4,67-4,26 cwt / ha/ 


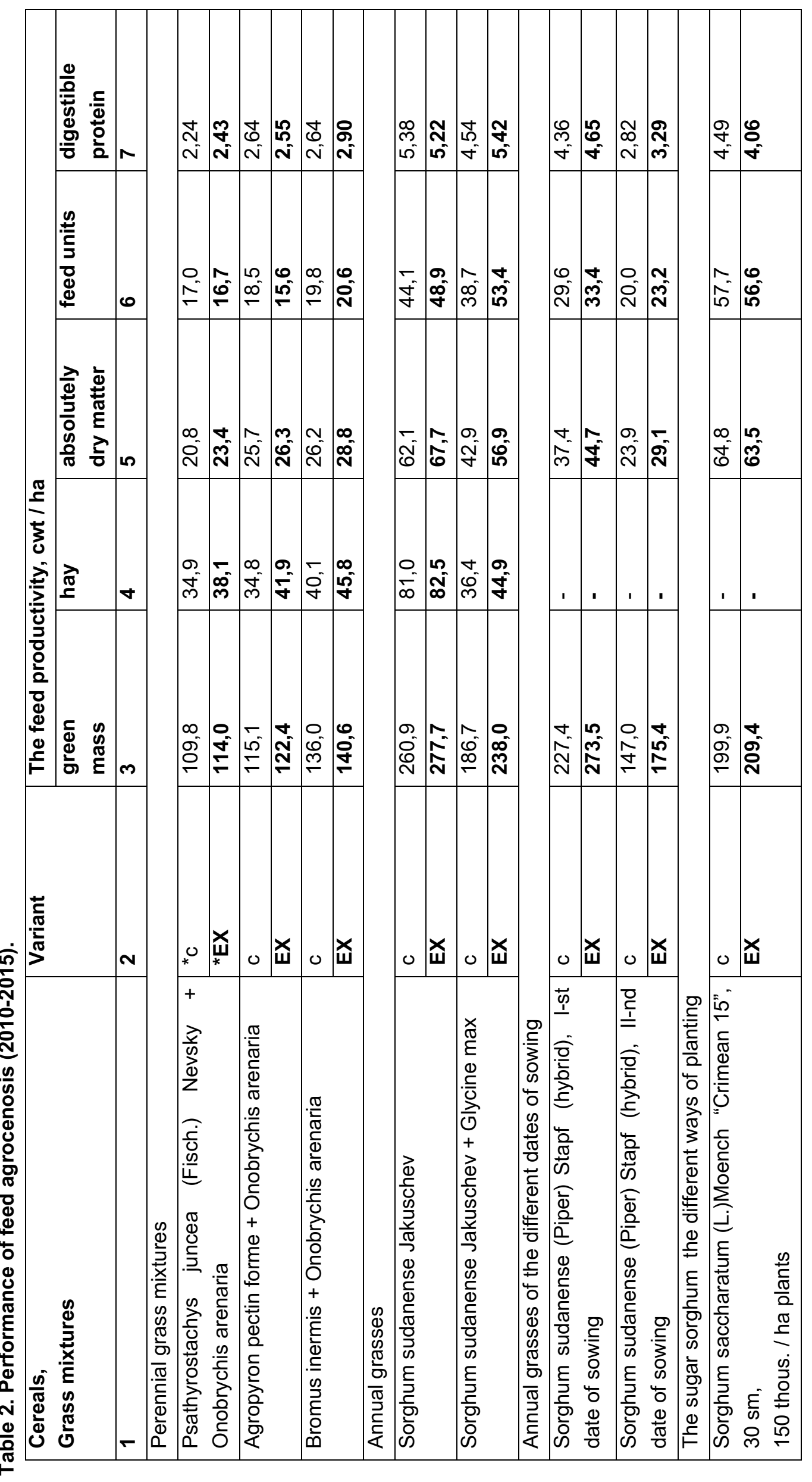







Found that the most effective way to create a pasture herbage of the sugar sorghum, it is the sowing of this crop with $45 \mathrm{~cm}$ row spacing and seeding rate of 150-200 thousand / ha plants with the application of bacterial drugs in preplant period.

On agrocenoses of feed raw conveyor for the gathering of hay into a phase of maturity, in average during years of researches, the perennial herbages productivity was 38,1-45, $9 \mathrm{cwt} /$ ha, while the fodder units output had 19, $0-22,9 \mathrm{cwt} / \mathrm{ha}$. The gain of the productivity to the control was 3, 2-7, $1 \mathrm{cwt} /$ ha or 1.5-3.5 cwt / ha of fodder units. The highest increase of the yield of green mass in comparison with the control was (7,1-5,7 cwt / ha) or $20,4-14,2 \%$, which was obtained for grass mixtures of Sainfoin with wheatgrass or Bromus inermis.

On average in 2011-2013, during two cycles of use, the herbages of Sudan grass in single-species and compatible with soy crops sowings had provided the gathering of hay in the experimental variants, respectively, 87.45 and $67.40 \mathrm{cwt} /$ ha, which exceeded the control on: 6.45 and $12.8 \mathrm{cwt} /$ ha or 7.9 and $23.4 \%$.

So, in the period of hay maturity the gathering of hay of perennial grasses was $38,1-45,9 \mathrm{cwt} / \mathrm{ha}$, which contained 19, 0-22, $9 \mathrm{cwt} /$ ha of fodder units, and of annuals herbages had - 87, 4-67, $4 \mathrm{cwt} /$ ha that contained $41,3-33,7 \mathrm{cwt} /$ ha of fodder units.

The herbage of Sudan grass defined as the most productive, which had on average during the years of researches and two cycles of use, $87.4 \mathrm{cwt} /$ ha of hay (control $81.0 \mathrm{cwt} /$ ha), to yield $41.3 \mathrm{cwt} /$ ha of fodder units and $495 \mathrm{cwt} / \mathrm{ha}$ of digestible protein.

In studies to create the raw feed conveyor for silage harvesting, the compatible sowings of sugar sorghum "Crimean 15" or corn "Elehiya" with Amaranth "Atlanta" were used, which reached silage maturity in the third decade of July. The average yield was of 206.3 and $192.2 \mathrm{cwt} /$ ha (control 174,2- 167.2 cwt / ha), increase of productivity amounted to $32,1-25,0 \mathrm{cwt} /$ ha or $18,4-14,9 \%$.

In experimental variants, single-species sowing of sugar sorghum and corn had such yield: 202.1 and $183.0 \mathrm{cwt} / \mathrm{ha}$ (control and $171.2162 .4 \mathrm{cwt} / \mathrm{ha}$ ) while the gain to control was 30.8 and $20,6 \mathrm{cwt} / \mathrm{ha}$ or 17 , 9-12, 7\%.

Among the silage agrocenoses, the joint sowings of sugar sorghum "Crimean 15" or corn "Elehiya" with amaranth "Atlant" were the most effective, which ensured the following yields: 206.3 and $192.2 \mathrm{cwt} /$ ha of green mass with yield 55.8- 55, $6 \mathrm{cwt} /$ ha of dry matter, 45, 4-44.9 cwt / ha of feed units and 4.77-5.30 cwt / ha of digestible protein.

Years of researches have proven that the effect of bacterial preparations on drought-resistant fodder crops is positive and cost-effective. The use of promising innovative varieties and biological products contributed to an increase in the yield of perennial forage grasses by $4.5-39.8 \%$, drought-resistant annual fodder crops - by $15.5-34.1 \%$ and to the production of ecologically friendly feeds.

The concentration of heavy metals in soils after cultivation of forage crops was within the limits: $\mathrm{Cd}$ - from 0,006 to $0,04 \mathrm{mg} / \mathrm{kg}$ (MPC $5 \mathrm{mg} / \mathrm{kg}$ ), $\mathrm{Pb}$ - from 0,12 to $0,83 \mathrm{mg} / \mathrm{kg}$ (Maximum allowable concentration is $32 \mathrm{mg} / \mathrm{kg}$ ), $\mathrm{Cu}$ is from 6.7 to $13.6 \mathrm{mg} / \mathrm{kg}$ (maximum permissible concentration is $20 \mathrm{mg} / \mathrm{kg}$ ), $\mathrm{Zn}$ is from 22 to $31 \mathrm{mg} / \mathrm{kg}$ (maximum permissible concentration is $70 \mathrm{mg} / \mathrm{kg}$ ). In the received samples of forages, the maintenance of harmful and polluting substances and as heavy metals did not exceed MPC.

An analysis of the economic efficiency of using perennial herbages for 4 years indicates that the cost price of pasturable forage in the experimental variants was 2.1-2.6 UAH / cwt (control 1.9-2.4 UAH / cwt) of fodder units - 14,3-18,9 UAN / cwt (the control is 13,0-15,2). The level of profitability is $97.3-143.3 \%$ (control 91.4-137.1\%), if products obtained with the use of biological products are sold at $10-15 \%$ more expensive (Table 3).

In the experimental variants, the cost price of pasture forage from a sorghum-Sudanese hybrid, with different planting times, was 6.79-4.11 UAH / cwt (control 7.47-4.52 UAH / cwt), fodder units - 51.3- 33.6 $\mathrm{UAH}$ /cwt (control 34.7-54.9 UAH / cwt). The level of profitability was 192.2-76.6\% (control 143.2-47.2\%).

In 2010, perennial grass mixtures ensured the yield of hay at the level of 34.8-45.8 cwt / ha (control 34.9$40.1 \mathrm{cwt} / \mathrm{ha}$ ), the prime cost was 12.9-15.5 UAH / ha (control 12, 9- $14.8 \mathrm{UAH} / \mathrm{cwt}$ ). The level of profitability was $74.5-109.7 \%$ (control $69.1-94.4 \%$ ). 
In the development of a raw material conveyor for harvesting coarse forages, the sowing of Sudan grass, and its mixtures with soybean, in experimental variants on arid lands, hay was produced in such volumes 82.5-44.9 cwt / ha (control 81.0-36, 4 centners per hectare), with its cost - 23.3-36.6 UAH. / ha (control of 24.5-41.3 UAH / ha). The level of profitability of the growing of Sudan grass for hay was $91.5 \%$, and its mixture with soybean was unprofitable.

In conditions of rainfed farming, during the experiments to create a pasture conveyor for obtaining green feed using sugar sorghum "Crimean15", sown with a seeding rate of 150 thousand ha of plants and $45 \mathrm{~cm}$ rows, the highest yield of green mass was obtained - $210.0 \mathrm{cwt} / \mathrm{ha}$ (control of $180.7 \mathrm{cwt} / \mathrm{ha}$ ), at a cost of green feed - $8.06 \mathrm{UAH}$ / cwt (control $8.9 \mathrm{UAH} / \mathrm{cwt}$ ). The level of profitability was $110.8 \%$ (control $69.5 \%$ ).

During the experiments on the cultivation of such crops as corn hybrids of different date's maturity and sugar sorghum in joint sowings with amaranth, it was established that these herbages reached silage ripeness in the third decade of July. The yield of sugar sorghum in sowings with amaranth was $206.3 \mathrm{c} /$ ha (control $174.2 \mathrm{cwt} / \mathrm{ha}$ ), the increment was $32.1 \mathrm{cwt} / \mathrm{ha}$ or $18.4 \%$, while in corn and amaranth sowings, these indicators were $192.2 \mathrm{cwt} / \mathrm{ha}$ (control of $167.2 \mathrm{cwt} / \mathrm{ha}$ ) or $25.0 \mathrm{cwt} / \mathrm{ha}(14.9 \%)$. The lowest cost price of green mass had sugar sorghum sowings with amaranth - $9.35 \mathrm{UAH} / \mathrm{cwt}$, their profitability level $146.1 \%$. For corn with amaranth, these figures were $10.8 \mathrm{UAH} / \mathrm{cwt}$ and $113.0 \%$.

In single-species sowings of sugar sorghum and corn, the cost of green mass was 8.57 and $9.83 \mathrm{UAH} /$ cwt with a profitability level of 168.4 and 134 . 


\begin{tabular}{|c|c|c|c|c|c|c|c|c|c|c|c|c|c|c|c|c|c|c|c|c|c|c|}
\hline \multicolumn{3}{|c|}{ 胥 } & \begin{tabular}{l|l}
$\dot{\sigma}$ & $m$ \\
$\bar{a}$ & $\sigma$
\end{tabular} & & $\stackrel{5}{\rightleftarrows}$ & & 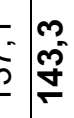 & & $\bar{\delta}$ & $\frac{1}{\pi}$ & \begin{tabular}{l|c}
0 & $c$ \\
$\infty^{-}$ & $\vdots$ \\
0 & $c$
\end{tabular} & $\frac{9}{5}$ & $\begin{array}{l}\dot{\sigma} \\
\dot{\sigma}\end{array}$ & & 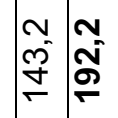 & 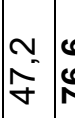 & $\begin{array}{l}0 \\
0 \\
0\end{array}$ & & 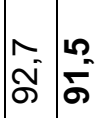 & $=\frac{3}{N}$ & in & ? \\
\hline \multicolumn{3}{|c|}{ 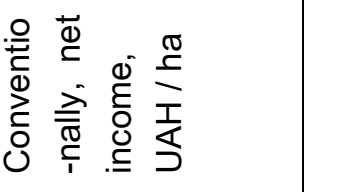 } & \begin{tabular}{l|l}
$\infty$ & \\
$\infty$ & 0 \\
& $\infty$ \\
\end{tabular} & & 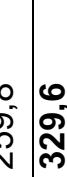 & & 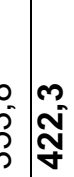 & & $\left|\begin{array}{l}n \\
0 \\
0^{\circ} \\
m \\
m\end{array}\right|$ & 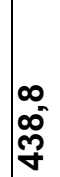 & $\begin{array}{l}0 \\
\mathfrak{m}^{2} \\
\vdots\end{array}$ & 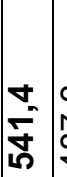 & & & 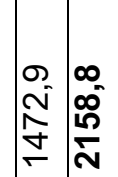 & 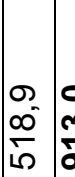 & $\begin{array}{c}0 \\
\frac{m}{\sigma}\end{array}$ & & 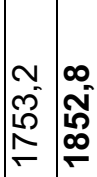 & $\begin{array}{l}0 \\
0 \\
0 \\
0 \\
0 \\
0\end{array}$ & ?ָ & 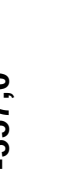 \\
\hline \multicolumn{3}{|c|}{ 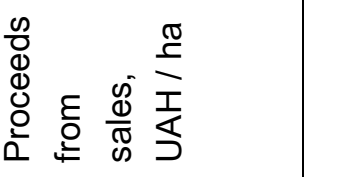 } & \begin{tabular}{l|l}
0 & + \\
& - \\
$\sigma$ & $\infty$ \\
\hdashline
\end{tabular} & & 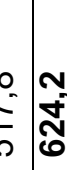 & 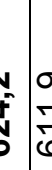 & $=\frac{d}{0}$ & & $\left|\begin{array}{l}n \\
\mathfrak{N} \\
\infty \\
\infty\end{array}\right|$ & 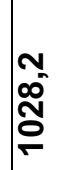 & $\begin{array}{lll}0 & 0 \\
0 & 0 \\
0 & \vdots \\
0 & \vdots \\
0 & \vdots\end{array}$ & 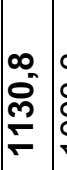 & 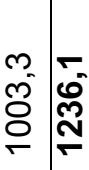 & & 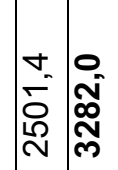 & 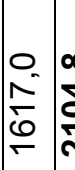 & $\begin{array}{l}\infty \\
\dot{0} \\
\frac{+}{N}\end{array}$ & & 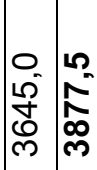 & $\begin{array}{l}0 \\
\vdots \\
\vdots \\
\infty \\
0 \\
0\end{array}$ & $\frac{m^{2}}{2}$ & ? \\
\hline \multicolumn{3}{|c|}{ 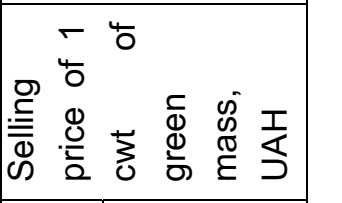 } & 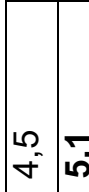 & & \begin{tabular}{l|l}
0 & - \\
$f$ & so $^{\circ}$
\end{tabular} & $5 \quad 5$ & sin & & $\mid \begin{array}{l}0 \\
\stackrel{0}{\mathfrak{N}^{0}}\end{array}$ & in & 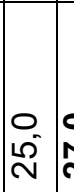 & 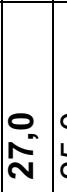 & \begin{tabular}{l|l}
0 & 0 \\
$\stackrel{N}{N}$ & \multirow{N}{N}{}
\end{tabular} & & $\begin{array}{l}0 \\
\stackrel{0}{=} \\
\stackrel{0}{\sim}\end{array}$ & & 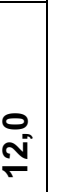 & & 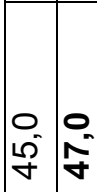 & $\begin{array}{l}0 \\
= \\
6\end{array}$ & i & 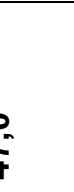 \\
\hline \multirow{3}{*}{ 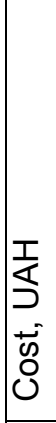 } & $-\frac{\bar{d}}{\frac{0}{0}}=$ & & \begin{tabular}{c|c} 
\\
\hdashline \\
0
\end{tabular} & s & 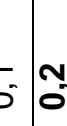 & 5 & 5 & & $\begin{array}{l}m \\
0 \\
0\end{array}$ & $\dddot{m}^{m}$ & $\begin{array}{ll}m & r \\
0^{\prime} & c\end{array}$ & 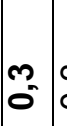 & \begin{tabular}{l|l}
$m$ & $m$ \\
0 & 0
\end{tabular} & & 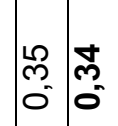 & \begin{tabular}{|l|l}
1 & 1 \\
1 & 1 \\
0 & 1 \\
0 & $c$
\end{tabular} & is & & \begin{tabular}{l|l}
$g$ & \multirow{f}{f}{} \\
0 & 0 \\
0 & 0
\end{tabular} & 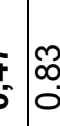 & $\begin{array}{l}0 \\
0 \\
0\end{array}$ & 5 \\
\hline & 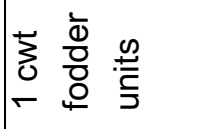 & & 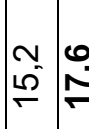 & 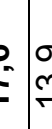 & \begin{tabular}{l}
$S$ \\
\hdashline \\
\hdashline \\
\hdashline
\end{tabular} & 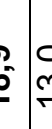 & 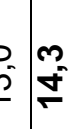 & & $\mid \begin{array}{l}0 \\
\tilde{N} \\
\tilde{N}\end{array}$ & $\frac{0}{m}$ & $\hat{D}$ & $\bar{c}$ & $\begin{array}{ll}\hat{N} \\
\stackrel{\sim}{n}\end{array}$ & & 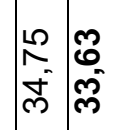 & 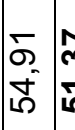 & 柋 & & 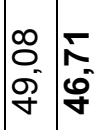 & $=\begin{array}{l}\infty \\
\infty \\
\infty \\
\infty \\
\infty\end{array}$ & 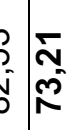 & 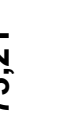 \\
\hline & 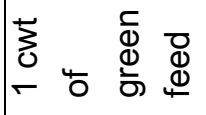 & & $\begin{array}{ll}\dot{N} & 0 \\
\sim & \end{array}$ & 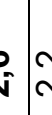 & 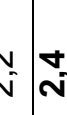 & $\stackrel{0}{5}$ & $=\bar{i}$ & & \begin{tabular}{l}
$\infty$ \\
\multirow{+}{*}{}
\end{tabular} & $\begin{array}{l}n \\
10 \\
2\end{array}$ & $\begin{array}{ll}\infty & 5 \\
& 5 \\
\end{array}$ & $\begin{array}{l}- \\
\square \\
\end{array}$ & 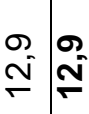 & ș & \begin{tabular}{l|l}
$\tilde{N}$ & $\mp$ \\
$\tilde{\sigma}$ & \multirow{\sigma}{*}{}
\end{tabular} & & $\begin{array}{l}\mathbb{R} \\
0 \\
0\end{array}$ & & \begin{tabular}{l|l}
$i$ & 0 \\
Ln \\
\multirow{N}{*}{}
\end{tabular} & 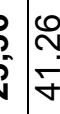 & $\begin{array}{l}\overline{0} \\
\bar{v} \\
\bar{j}\end{array}$ & 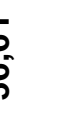 \\
\hline \multicolumn{3}{|c|}{ 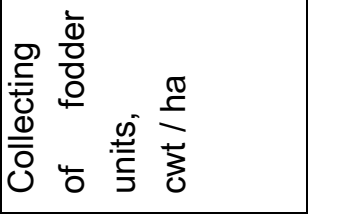 } & \begin{tabular}{l|l}
0 & \multirow{2}{*}{} \\
& 0
\end{tabular} & $=\frac{b}{a}$ & & & $\begin{array}{l}0 \\
0 \\
0 \\
0\end{array}$ & & 售 & o & $\stackrel{\Delta}{\sim}$ & $\begin{array}{l}9 \\
\text { Nิ }\end{array}$ & 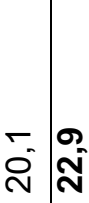 & & \begin{tabular}{l|l}
0 & $\forall$ \\
S & D
\end{tabular} & 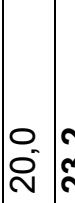 & ָे & & \begin{tabular}{l|l}
10 \\
\end{tabular} & & 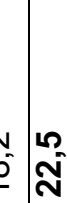 & j \\
\hline \multicolumn{3}{|c|}{ 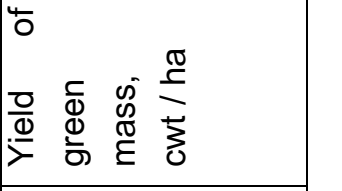 } & 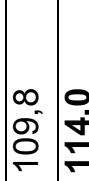 & $\frac{7}{7}$ & 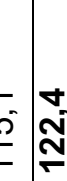 & 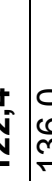 & 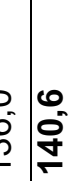 & & 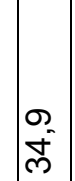 & $\bar{\infty}_{\infty}^{-}$ & $\begin{array}{l}\infty \\
\mathcal{m}^{n} \\
\vdots\end{array}$ & $\mid$ & 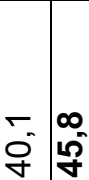 & & 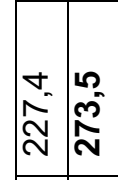 & 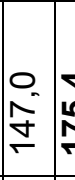 & م & & \begin{tabular}{|l|l}
0 & $\infty$ \\
$\infty$ & $\mathbb{N}$ \\
$\infty$ & $\infty$ \\
\end{tabular} & $\begin{array}{l}J \\
0 \\
0\end{array}$ & f & ? \\
\hline \multicolumn{3}{|c|}{ 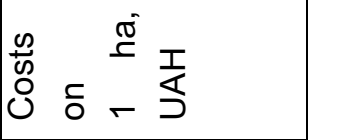 } & 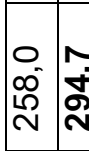 & $\begin{array}{l}c \\
f \\
\alpha \\
5 \\
5\end{array}$ & \begin{tabular}{l|l}
0 \\
0 \\
0
\end{tabular} & & ט. & $\begin{array}{l}\mathscr{D} \\
\mathbb{\infty} \\
\mathscr{D} \\
\mathbb{N} \\
\mathbb{N}\end{array}$ & $\left|\begin{array}{c}0 \\
0 \\
\frac{6}{10}\end{array}\right|$ & $\begin{array}{l}m \\
8 \\
\infty \\
0\end{array}$ & \begin{tabular}{l|l}
0 & 9 \\
0 & 0 \\
$i n$ & 0
\end{tabular} & 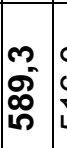 & $\begin{array}{ll}0 & m \\
0 & 0 \\
0 & 0 \\
\infty & 0 \\
0\end{array}$ & & 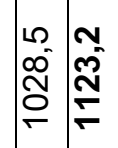 & 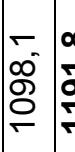 & $\begin{array}{l}\infty \\
\frac{\infty}{\sigma} \\
\frac{n}{\sigma}\end{array}$ & & 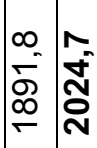 & $=\begin{array}{l}0 \\
\infty \\
N \\
N \\
N\end{array}$ & 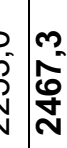 & ? \\
\hline \multicolumn{2}{|c|}{ 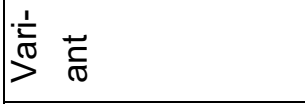 } & & u & & ט & క & | & $\begin{array}{l}\frac{\bar{\sigma}}{\bar{c}} \\
\frac{\bar{c}}{\Phi}\end{array}$ & 0 & 땀 & 0 & 爻 & 0 & & 0 & 0 & 宏 & ב) & 0 & J & ט & 5 \\
\hline \multicolumn{2}{|c|}{ 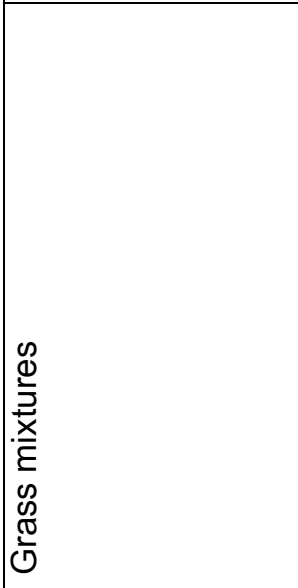 } & & 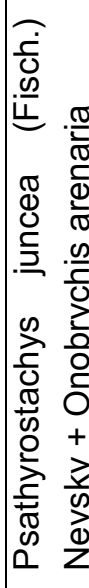 & 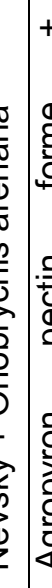 & 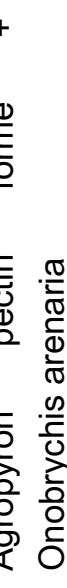 & 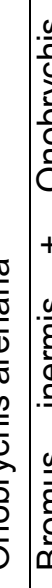 & 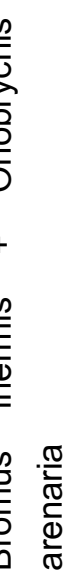 & 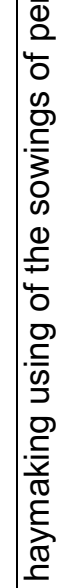 & 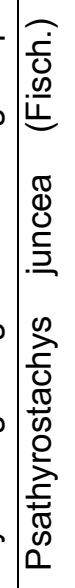 & 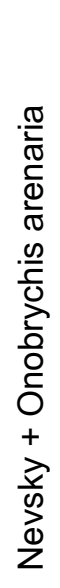 & 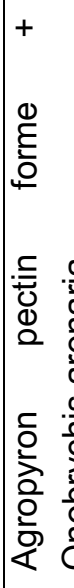 & 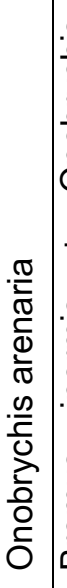 & 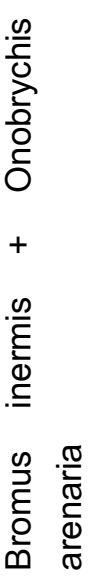 & 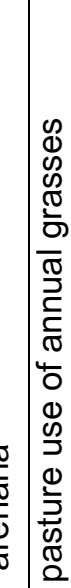 & 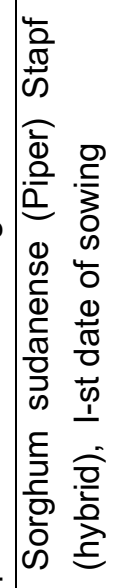 & 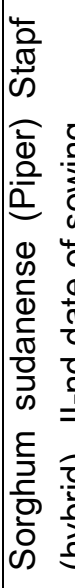 & 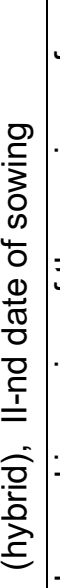 & 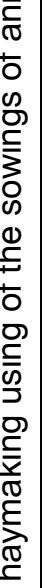 & 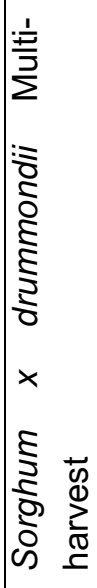 & 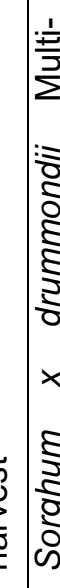 & 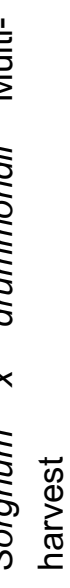 & 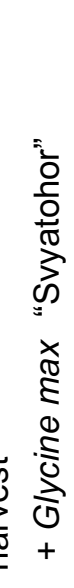 \\
\hline 인 & & 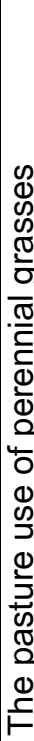 & $\stackrel{\circ}{\circ}$ & r & v & c & $\dot{p}$ & $\underline{\underline{E}}$ & & $\therefore$ & $\sim$ & & $\dot{m}$ & $\stackrel{\oplus}{E}$ & 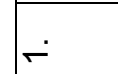 & N & & $\stackrel{\oplus}{E}$ & ${ }^{\circ}$ & & vi & \\
\hline
\end{tabular}




\begin{tabular}{|c|c|c|c|c|c|c|c|c|c|c|c|c|c|c|c|c|c|}
\hline$\stackrel{m}{=}$ & & 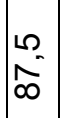 & $\stackrel{\infty}{\stackrel{\infty}{\sigma}}$ & 足 & 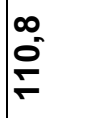 & $\left|\begin{array}{l}\infty \\
\infty \\
0 \\
0\end{array}\right|$ & $\frac{\infty}{\sigma}$ & $\begin{array}{l}\infty \\
8 \\
0 \\
0\end{array}$ & $\begin{array}{l}\infty \\
\infty \\
\infty \\
\infty\end{array}$ & & $\mid \begin{array}{l}\infty \\
\infty \\
\infty \\
o\end{array}$ & $\begin{array}{c}- \\
\dot{\sigma} \\
\dot{\sigma}\end{array}$ & 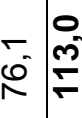 & 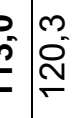 & $\begin{array}{l}8 \\
0 \\
0 \\
0\end{array}$ & & @ \\
\hline$\cong$ & & 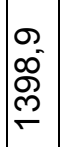 & $\mid \begin{array}{c}\hat{N} \\
0 \\
\infty \\
\infty \\
\sigma\end{array}$ & $\mid$ & $\begin{array}{l}\hat{N} \\
0 \\
0 \\
\infty \\
-\end{array}$ & 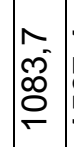 & 壳 & 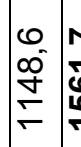 & 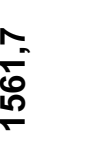 & & 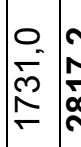 & $\underset{\sim}{\mathfrak{N}}$ & 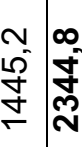 & 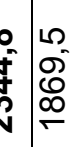 & న్ & & 足 \\
\hline$\mp$ & & $\begin{array}{l}10 \\
\infty \\
\mathbb{D}^{\circ} \\
\stackrel{D}{N}\end{array}$ & 足 & 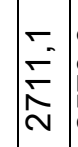 & 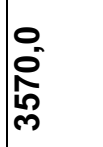 & $\mid$ & 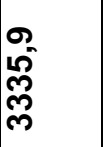 & 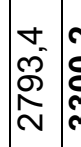 & ָू & & $\begin{array}{c}\sim \\
\tilde{N} \\
\infty \\
\tilde{m} \\
\tilde{m}\end{array}$ & $\begin{array}{c}0 \\
S^{-} \\
\checkmark \\
\checkmark\end{array}$ & 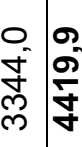 & 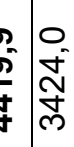 & 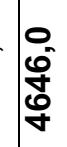 & & ㅇ. \\
\hline$ㅇ ㅡ$ & & $\begin{array}{l}0 \\
10^{\circ} \\
-2\end{array}$ & $\stackrel{0}{\stackrel{0}{5}}$ & $\begin{array}{c}0 \\
10^{\circ}\end{array}$ & $\stackrel{0}{\circ}$ & $\begin{array}{l}0 \\
10 \\
12\end{array}$ & $\stackrel{0}{\stackrel{0}{*}}$ & $\begin{array}{c}0 \\
15^{\circ} \\
7\end{array}$ & $\stackrel{0}{\circ}$ & & Õ & $\stackrel{0}{\substack{-\tilde{N}}}$ & 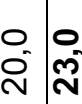 & 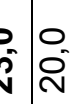 & స్ & 悹 & 올 \\
\hline 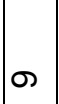 & & 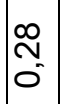 & হ্ণ & $\begin{array}{c}\bar{m} \\
0 \\
0\end{array}$ & న్ & 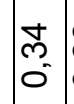 & 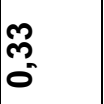 & $\begin{array}{c}\approx \\
\tilde{c} \\
0 \\
0\end{array}$ & 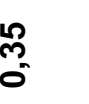 & & $\mathcal{Z}_{0}$ & צे & 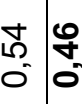 & 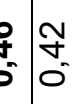 & $\underset{\delta}{\tau}$ & & o \\
\hline$\infty$ & & 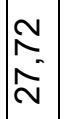 & $\begin{array}{l}\stackrel{8}{0} \\
\text { స్ }\end{array}$ & $\mid \begin{array}{l}\frac{0}{\bar{m}} \\
\overline{\check{m}}\end{array}$ & 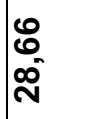 & $\begin{array}{l}m \\
\infty \\
\tilde{m} \\
\tilde{m}\end{array}$ & స్⿱一⿻上丨⿹ & $\begin{array}{l}\stackrel{2}{N} \\
\tilde{N} \\
\tilde{m}\end{array}$ & 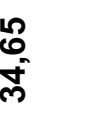 & & 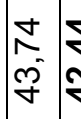 & $\begin{array}{l}\forall \\
\mathcal{Y} \\
\mathcal{Y}\end{array}$ & 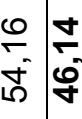 & 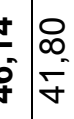 & 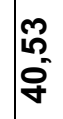 & & R \\
\hline$\wedge$ & & $\begin{array}{l}8 \\
\infty \\
\infty\end{array}$ & $\begin{array}{l}8 \\
\infty \\
\infty\end{array}$ & $\left|\begin{array}{l}\infty \\
\infty \\
\infty\end{array}\right|$ & $\begin{array}{l}\mathscr{8} \\
\infty \\
\infty\end{array}$ & $\left|\begin{array}{l} \pm \\
0 \\
\sigma\end{array}\right|$ & $\begin{array}{l}0 \\
\infty \\
\infty \\
\infty \\
\infty\end{array}$ & \begin{tabular}{c|c} 
& 0 \\
$\infty$ & 0 \\
$\infty$ & 0 \\
$\infty$
\end{tabular} & 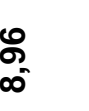 & & $\mid \begin{array}{l}0 \\
0 \\
0 \\
0 \\
0\end{array}$ & డొ & 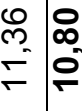 & 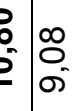 & $\begin{array}{l}n \\
\omega_{0} \\
\infty\end{array}$ & & $\begin{array}{l}\infty \\
\infty \\
\infty \\
\sigma\end{array}$ \\
\hline 0 & & $\begin{array}{l}\bar{N} \\
\text { in } \\
\text { in }\end{array}$ & $\begin{array}{l}8 \\
6 \\
0 \\
60\end{array}$ & 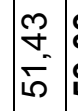 & $\begin{array}{l}\text { 요 } \\
\text { ô }\end{array}$ & $\mid \begin{array}{c}\mathcal{O} \\
\mathcal{O} \\
0^{-} \\
\mathcal{+}\end{array}$ & חొ & $\begin{array}{l}8 \\
\frac{-}{50} \\
\end{array}$ & مَ' & & 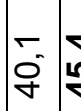 & & $\begin{array}{c}\bar{m} \\
\bar{c}\end{array}$ & 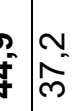 & $\hat{\mathcal{F}}$ & & $\underset{\sim}{\sim}$ \\
\hline 10 & & 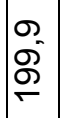 & ণ্ & 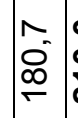 & $\stackrel{0}{\stackrel{0}{N}}$ & $\begin{array}{c}\sigma \\
- \\
\infty \\
-\end{array}$ & 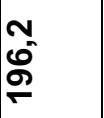 & 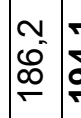 & g & & 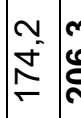 & \begin{tabular}{c}
$m$ \\
\hdashline \\
0 \\
\hdashline
\end{tabular} & 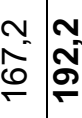 & 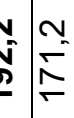 & ㅇ. & & $\begin{array}{l}0 \\
\infty \\
\infty \\
\infty \\
\infty\end{array}$ \\
\hline | & & 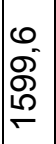 & 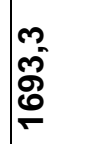 & 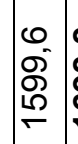 & ్ֶ & $\mid$ & 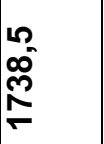 & 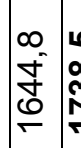 & 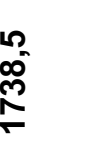 & & 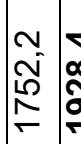 & 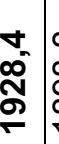 & 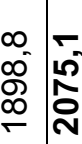 & 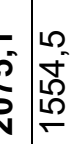 & 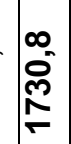 & $\begin{array}{l}\mathfrak{N} \\
\mathbb{N} \\
\mathscr{O}\end{array}$ & $\begin{array}{l}\infty \\
\infty \\
\infty \\
\stackrel{2}{*}\end{array}$ \\
\hline$m$ & & 0 & u & 0 & 希 & 0 & 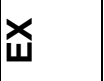 & 0 & 齐 & & 0 & 宏 & o & \begin{tabular}{l|l}
5 & 0
\end{tabular} & 爻 & & x \\
\hline$N$ & 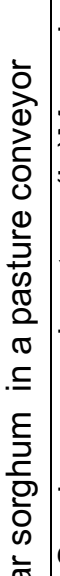 & 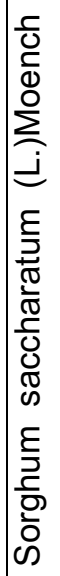 & 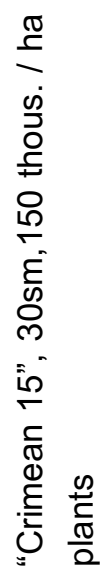 & 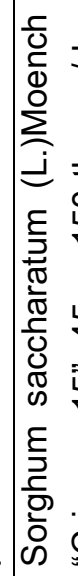 & 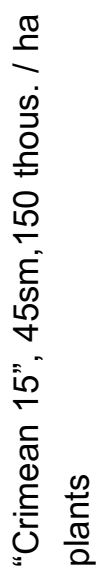 & 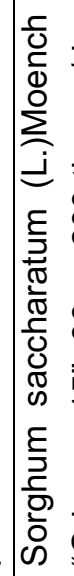 & 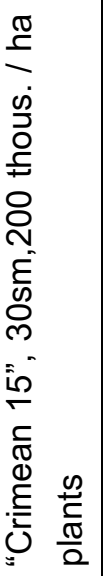 & 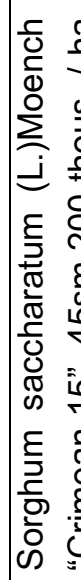 & 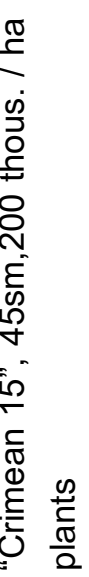 & 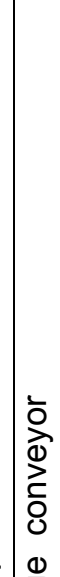 & 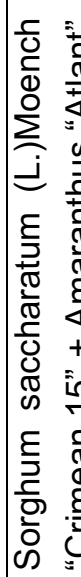 & 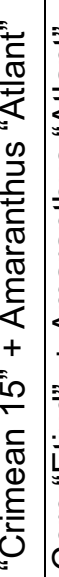 & 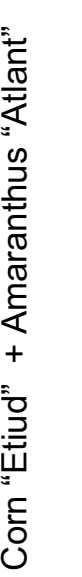 & 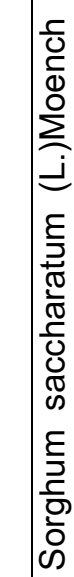 & 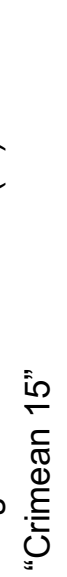 & 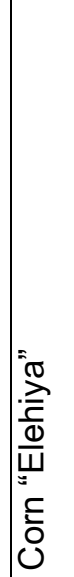 & \\
\hline- & ஸे. & & & $\mathbf{v}$ & & m & & $\dot{\nabla}$ & & 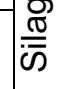 & 5 & & N & m & & \& & \\
\hline
\end{tabular}




\section{Conclusions}

The technology of agro ecological production of feed in the conditions of rainfed farming is developed on the basis of the requirements for organic production of this type of product, its components are:

- agrocenosis of drought-resistant perennial grass mixtures (Psathyrostachys juncea (Fisch.) Nevsky, Agropyron pectin forme, Bromus inermis with Onobrychis arenaria) with a yield of green mass of 114.0140.6 cwt / ha, containing 23.4-28.8 cwt / ha of dry matter, $156-20.6 \mathrm{cwt} /$ ha of feed units and 1.65-2.90 cwt / ha of digestible protein; the yield of hay is 38.1-45.8 cwt / ha with a content of 19.0-22.9 cwt / ha of feed units; prime cost of green mass - $2.35 \mathrm{UAH} /$ cwt with a profitability level of $120.3 \%$;

- Agrocenoses of annual drought tolerant fodder crops, which have high yields with the aftergrass: a Sorghum-Sudanese hybrid, with different planting times, has an average yield of $224.5 \mathrm{cwt} / \mathrm{ha}$ of green mass, a cost price of $5.45 \mathrm{UAH} / \mathrm{cwt}$ and a profitability level of $134.4 \%$; Sudan grass in singlespecies and joint sowings with soybeans, has a hay yield of 63.7 centners per hectare with a cost of 29.9 UAH per centners and a profitability level of 91.5 per cent; Sugar Sorghum and Corn with Amaranth for use on silage with a yield of 206.3 and 192.2 centner / ha of green mass, yielding 55.853.8 centner / ha of dry matter, 45.4-44.09 centner / ha fodder units and 4.73-4.52 cwt / ha of digestible protein and costing $10.1 \mathrm{UAH} / \mathrm{cwt}$, the level of profitability $-129.5 \%$.

Found that the most effective way to create a pasture with herbage of Sugar Sorghum is it's sowing with row spacing of $45 \mathrm{~cm}$ and seeding rate of 150-200 thousand / ha and the application of the preplant treatment of plants with bacterial drugs.

The technological way of pre-treatment of seeds of forage crops by nitrogen-fixing bacterial agents, mobilizing of phosphates and phytopathogenic action, had provided an increase in productivity of perennial grasses in $14,2-24,0 \%$, annual crops - 7,9-23,4\%.

The concentration of heavy metals in soils after growing forage crops located within: $\mathrm{Cd}$ - from 0.006 to $0.04 \mathrm{mg} / \mathrm{kg}$ (MPC - $5 \mathrm{mg} / \mathrm{kg}$ ), Pb - from 0.12 to $0.83 \mathrm{mg} / \mathrm{kg}$ (MPC $-32 \mathrm{mg} / \mathrm{kg}$ ), Cu - from 6.7 to $13.6 \mathrm{mg} / \mathrm{kg}$ (MPC -20mh / kg), Zn - from 22 to $31 \mathrm{mg} / \mathrm{kg}$ (MPC $-70 \mathrm{mg} / \mathrm{kg}$ ).

The content of harmful pollutants and heavy metals in samples of feed, which we derived, and in the soil during the growing of fodder agrocenosis, did not exceed the MPC that was a prerequisite for the production of organic vegetable feed raw materials.

\section{Bibliography}

1. Petrychenko V.F. Naukovi osnovy staloho rozvytku kormovyrobnytsva [Scientific basis for sustainable development of fodder production] / V.F. Petrychenko //Visnyk of Agricultural Science. 2006. - №3-4. - p.72-74.

2. Vidnovlennya travyanystukh bioheotsenoziv na vyluchenykh iz obrobitku ornykh zemlyakh [Restoration the grassy biogeocenosis on the withdrawn from cultivation of arable land] / [ V.F. Sayko, A.B. Bohovin, S. H. Korsunvydynyuk ta insh.] // Visnyk of Agricultural Science. - 2006. - № 9. - p. 8-12.

3. Nazarov Ye. A. Sistyema proizvodstva kormov $v$ Krasnodarskom kraye Possii, uchityvayushchaya factor globalnogo poteplyeniya klimata [The fodder production system in the Krasnodar Krai of Russia, taking into account the global warming factor] / [Ye. A. Nazarov, A.N. Riger, S.I. osetskiy] (in Russian) // Kormy i kormovyrobnytsvo: mizhvid. tematych. nauk. zb. [Feed and fodder production, interdepartmental thematic scientific collection] - Vinnytsya, 2008. - Vyp. 62. - p. 78-83.

4. Zastosuvannya biopreparativ na osnovi agronomichno korysnykh mikroorhanizmiv v suchasnukh ahrotekhnolohiyakh [The use of biologics through agronomically useful microorganisms in modern agricultural technologies] / [T.M. Myelnychuk, M.K. Sherstoboyev, I.O. Kamenyeva ta insh.] // Byuleten rehionalnoho Tsentra naukovoho zabezpechennya ahropromyslovoho vyrobnytstva Avtonomnoyi Respublyky Krym. [Bulletin of the Regional center of scientific providing of agricultural production Autonomous Republic of Crimea] - 2009. - № 11. - P. 8. 
5. Biologizatsiya agrotekhnologiy vyrashchivaniya bobovyh trav [Biologization of agro technologies for the cultivation of legumes] / [S. V. Didovich, A.V. Prihodko, V.V. Naumenko I dr.] // Byuleten rehionalnoho Tsentra naukovoho zabezpechennya ahropromyslovoho vyrobnytstva Avtonomnoyi Respublyky Krym. [Bulletin of the Regional center of scientific providing of agricultural production Autonomous Republic of Crimea] - 2010. - № 12. - p. 3-7. ] (in Russian)

6. Peytrychenko V..F. Polyove trovosyannya v systemi konveyernoho vyrobnytstva kormiv v Ukraini [The field sowing of grasses at the system of conveyor production of feed in Ukraine] / V.F. Petrychenko, H.P. Kvitko // Visnyk of Agricultural Science. - 2004. - № 3. - p. 31-32.

7. Byelyevich Ye. I. Odnorichni kultury dlya stvorennya rezervnoho vypasu na period litnyoi depresii bahatorichnykh pasovyshch $v$ stepovykh rayonakh Kubani [Annual crops to create of reserve pasture on the period of summer depression of the perennial pastures in the steppe regions of Kuban] / Ye. I. Byelyevich // Kormy i kormovyrobnytsvo: mizhvid. tematych. nauk. zb. [Feed and fodder production, interdepartmental thematic scientific collection] - Vinnytsya: Theses, 2003. - Vyp. 51. - p. 261-263.

8. Shepel M.A. Sorhovi kultury prosyatsya na lany Ukrainy [Sorghum crops are asking to the fields of Ukraine] / M.A. Shepel // Propozytsiya. 2004. - № 6. - p. 54-56.

9. Bova V.M. Bahotorichni kormovi kultury u vyrobnytstvi zelenukh kormiv dlya ovets na pivdni Ukrainy [Perennial forage crops in the production of green fodder for sheep in southern Ukraine] / V.M. Bova // Vivcharstvo: : mizhvid. tematych. nauk. zb. [Sheep breeding: interdepartmental thematic scientific collection] - Kyiv: Urozhay, 1990. - Vyp. 27. - p. 62-64.

10. Bova V.M. Pasovishcha dlya ovets u posushlyvomu stepu Ukrainy [Pastures for sheep in the arid steppe of Ukraine] / V.M. Bova // Vivcharstvo: : mizhvid. tematych. nauk. zb. [Sheep breeding: interdepartmental thematic scientific collection] - Kyiv: Urozhay, 1998. - Vyp. 30. - p. 131-134.

11. Shepel N.A. Sorgo - intensivnaya kultura [Sorghum - the intensive crop] N.A. Shepel. Simferopol: Tavriya, 1998. - 192 p. (in Russian)

12. Makarenko P.S. Osnovni element resurso- i enerhozberezhennya v lukivnytstvi v suchasnykh umovakh [The main elements of resource and energy conservation in meadow management in modern conditions] P.S. Makarenko // Kormy i kormovyrobnytsvo: mizhvid. tematych. nauk. zb. [Feed and fodder production, interdepartmental thematic scientific collection] - Vinnytsya: Theses, 2003. Vyp. 51. - p. 227-230.

13. Otsinka kormovoyi produktyvnosti sortiv I kolektsiynykh sortozpazkiv posukhostiykykh vydiv zlakovykh bahatorichnykh trav $v$ umovakhboharnoho zemlerobstva pivdnya Ukrainy [Assessment of fodder productivity of the varieties and collector varieties of drought-resistant species of grassy perennial grasses in conditions of rainfed agriculture in the south of Ukraine] / [O.D. Hratylo, V.F. Smyenov, H.S. Smyenova ta insh.] IIII Kormy i kormovyrobnytsvo: mizhvid. tematych. nauk. zb. [Feed and fodder production, interdepartmental thematic scientific collection] - Vinnytsya, 2012. - Vyp. 73. - p. 21-29.

14. Hratylo O.D. Ekonomichna otsinka efectyvnosti vyroshchuvannya kormiv $\mathrm{v}$ umovakh posushlyvoho stepu pivdnya Ukrainy [Economic evaluation of the efficiency of growing forage crops and feed production under conditions in the south steppe of Ukraine] / O.D. Hratylo, V.F. Smyenov, H.S. Smyenova // Visnyk TSNZ APV Kharkivska region. - Kharkiv, 2010. - Vyp. 8. - p. 256-266.

15. Babich A.O. Metodyka provedennya doslidiv po kormovyrobnytstvu [Method of carrying out the experiments on forage production] / A.O. Babich - Kyiv: Agrarna Nauka, 1994. - 78 p.

16. Metodika opytov na syenokosakh i pastbishchakh [Technique of experiments on hayfields and pastures] VNIIK: pod red. V.G. Iglovikova. - Moscow, 1971 - Part 2. - 118 p. (in Russian)

17. Dospehov B.A. Metodika polyevogo opyta s osnovami statisticheskoy obrabotki rezultatov isslyedovaniy [Methodology of field experience with the basics of statistical processing of research results] / B.A. Dospehov. - Moscow: Agropromizdat, 1985. - 352 p. (in Russian)

18. Recomendatsiyi $\mathrm{z}$ efectyvnoho zastosuvannya mikrobnykh preparative $\mathrm{u}$ tekhnolohiyakh vyroshchuvannya silskohospodarskykh kultur [Recommendations for effective use of microbial agents in technologies of growing crops] // [S.I. Melnik, V.A. Zhylkin, M.M. Havrylyuk ta insh.] - Kyiv, 2007. - 52 p. 